\title{
A audiência pública do TST sobre terceirização como espaço social de luta político-cognitiva
}

\section{Attila Magno e Silva Barbosa' Rodrigo Hinz da Silva ${ }^{2}$}

\section{Resumo}

O Tribunal Superior do Trabalho (TST), diante da existência, em seu âmbito, de cerca de 5.000 recursos discutindo a licitude da terceirização, assim como de milhares de outros tramitando por toda a Justiça do Trabalho, em iniciativa inédita, convocou, no dia 9 de agosto de 201 I, uma audiência pública sobre terceirização. Realizada nos dias 4 e 5 de outubro de 201 I, foram selecionados 51 oradores de diversas correntes de opinião, entre juristas, economistas, sociólogos, sindicalistas, representantes patronais, parlamentares, administradores de empresa, entre outros, para manifestarem-se em apresentações de 15 minutos, nas quais todos puderam expor informações, seus argumentos e posicionamentos sobre a matéria. O debate nela ocorrido ordenou-se no sentido de fazer emergir no TST, se não uma visão definitiva, ao menos uma visão mais bem consubstanciada sobre as implicações sociais, econômicas e políticas que o uso da terceirização produz e que a sua eventual extensão pode produzir. Neste artigo, nossa proposta é analisar a referida audiência como um espaço social de lutas político-cognitivas pela definição do real. No caso em questão, isto significa a busca do TST por subsidios cognitivos que permitam consubstanciar uma linha de entendimento sobre a terceirização a partir das informações, dos argumentos e dos posicionamentos trazidos pelos diversos agentes sociais que nela se fizeram presentes.

Palauras-chave: Flexibilização das relações do trabalho. Terceirização. Luta político-cognitiva.

\section{Introdução}

No Brasil, a terceirização tem sido amplamente utilizada como estratégia de redução de custos com força de trabalho, a despeito das alegaçóes de seus entusiastas de que a principal intenção seja utilizá-la como uma técnica de focalização empresarial que objetiva o aperfeiçoamento das atividades

I Doutor em Sociologia pela Universidade Federal de São Carlos. Professor do Instituto de Filosofia, Sociologia e Política e do Programa de Pós-Graduação em Sociologia da Universidade Federal de Pelotas.

E-mail: barbosaattila@uol.com.br

2 Mestre em Sociologia pela Universidade Federal de Pelotas. E-mail: rodrigohinzdasilva@msn.com 
consideradas centrais e, consequentemente, o aumento de competitividade. Em outras palavras, tem sido utilizada no sentido de descaracterização do vínculo empregatício do trabalhador terceirizado junto à empresa tomadora de serviços objetivando a desoneração do conjunto de encargos trabalhistas que tal vinculação jurídica acarreta.

Nos últimos anos, as batalhas judiciais travadas nos tribunais trabalhistas brasileiros têm recrudescido com a ausência de uma legislação específica que regulamente as novas modalidades de terceirização. Essa situação fomenta não apenas uma luta política e cultural nos tribunais trabalhistas no sentido de definir o entendimento dominante sobre o tema, mas, sobretudo, no âmbito da própria sociedade com relação ao papel que a terceirização deva desempenhar no cenário econômico brasileiro. O momento de indefiniçáo provocado por essa situação tende a criar brechas legais que possibilitam às grandes empresas reduzirem o círculo de funçôes ligadas à atividade-fim e, consequentemente, estender o uso da terceirização.

Nesse sentido, o Tribunal Superior do Trabalho (TST) realizou, nos dias 4 e 5 de outubro de 2011, audiência pública ${ }^{3}$ para ouvir o pronunciamento de especialistas e autoridades sobre o tema da terceirização. A intenção do TST foi promover um espaço para apresentação das diversas posiçóes e interpretaçôes de agentes sociais que, de alguma maneira, estáo envolvidos com o tema, visando a contribuir para o esclarecimento de inúmeros questionamentos sobre os modos como a terceirização tem sido utilizada no Brasil. Ao todo, foram selecionados 51 oradores - entre juristas, economistas, sociólogos, sindicalistas, deputados federais, representantes patronais, entre outros -, para manifestarem-se em apresentaçôes de 15 minutos, nas quais apresentaram informaçóes e defenderam seus argumentos e posicionamentos sobre o tema da terceirização.

Neste artigo, a proposta é analisar a referida audiência como um espaço social no qual, nos termos de Bourdieu (2007b), se pode "apreender relacionalmente o mundo social", pois a realidade se apresenta na "exterioridade mútua dos elementos" que compóem um campo de disputas por ela ordenado. No caso em questão, isso significa a busca do TST por subsídios cognitivos que

3 Todas as falas transcritas neste artigo estão disponibilizadas em vídeos no canal oficial do Tribunal Superior do Trabalho (TV TST, 20 I la, 20 I b, 20 I c, 20 IId, 20 IIe, 20 IIf) 
permitam consubstanciar uma linha de entendimento sobre a terceirização a partir dos argumentos, posicionamentos e informaçóes trazidos pelos diversos agentes sociais que nela se fizeram presentes. Em outras palavras, analisaremos especificamente os diferentes posicionamentos dos oradores que participaram da audiência pública, procurando compreendê-los como constitutivos de um espaço social de lutas político-cognitivas pela definição do real (TV TST, 2011a, 2011b, 2011c, 2011d, 2011e, 2011f). Mas, antes disso, na primeira seção, apresentaremos um breve panorama de como a terceirização tem sido tratada pelo Direito do Trabalho no Brasil.

\section{A terceirização no direito do trabalho brasileiro}

$\mathrm{Na}$ ausência de um marco regulatório sobre a terceirização, as correntes doutrinárias do Direito do Trabalho e os entendimentos jurisprudenciais confrontam-se via manifestaçôes em juízo dos operadores do Direito, isto é, juízes, procuradores do trabalho e advogados nas diferentes instâncias da Justiça do Trabalho. As titulaçóes desses agentes, conferidas e reconhecidas pelo poder estatal, não apenas lhes atribuem o monopólio dos serviços jurídicos mas também o "poder simbólico"4 das construçôes jurídicas. Assim, a luta político-cognitiva sobre a terceirização configura-se nas práticas judiciais por meio de um embate entre os argumentos alinhados a uma flexibilização de desregulamentação, a uma flexibilização de adaptação, a uma flexibilização de proteção ou mesmo à imposição de normas jurídicas que restrinjam, ao máximo, essa prática empresarial. Isso significa afirmar que, o escopo dessa luta político-cognitiva não se limita à terceirização. Sua abrangência refere-se à flexibilização das relaçôes de trabalho e aos efeitos sociais e econômicos que dela decorrem.

4 Nas palauras de Bourdieu (1998b, p. 9): "[...] é um poder de construção da realidade que tende a estabelecer uma ordem gnosiológica: o sentido imediato do mundo (e, em particular, do mundo social) supõe aquilo a que Durkheim chama de conformismo lógico, quer dizer, 'uma concepção homogênea do tempo, do espaço, do número, da causa, que torna possivel a concordância entre as inteligências". E esse autor, em outra obra. complementa: "[...] é o poder que se cria, se acumula e se perpetua em virtude da comunicação e da troca simbólica entre agentes inseridos em uma ordem de conhecimento e de reconhecimento (não quer dizer atos intencionais de consciência) que "[...] converte relações de força bruta, sempre incertas e suscetiveis de serem suspensas, em relações duráveis de poder simbólico pelas quais se é obrigado e com as quais se sente obrigado" (BOURDIEU, 2007a, p. 242) 
Com esse campo de disputas em vista, juridicamente falando, a terceirização caracteriza-se pela entrega de determinada atividade periférica para ser realizada de forma autônoma por empresa especializada, não podendo ser confundida com simples fornecimento de mão de obra. Esta última, inclusive, condenada pela Organização Internacional do Trabalho (OIT) em seu primeiro princípio: o "trabalho não é mercadoria". No Brasil, a terceirização em si não é ilegal, mas sim a intermediação de mão de obra, isto é, o fornecimento de trabalhadores (CARELLI, 2007, 2010).

Segundo Carelli (2007), no Direito brasileiro, o Código Civil de 1916 fez a primeira previsão legal sobre "locação de serviços". Em 1943, com o advento da Consolidação das Leis do Trabalho (CLT), as regras contratuais referentes a essa modalidade de trabalho foram revogadas no que se referia ao trabalho realizado de forma subordinada. Nesse mesmo diploma legal, também houve previsão para o instituto da "empreitada" (arts. 1237/1247), tipo de externalização largamente utilizada no setor da construçáo civil (CARELLI, 2007, p. 60). No caso da CLT, somente o art. 455 tratou de terceirização, e tão somente na forma de empreitada, impondo inclusive a responsabilidade solidária do empreiteiro principal com o subempreiteiro pelo adimplemento das obrigaçôes trabalhistas nos contratos de subempreitada. Conforme Carelli (2007, p. 60):

O primeiro dispositivo da legislação trabalhista a dispor sobre a terceirização tratou sobre a chamada 'quarteirização' ou 'terceirização em cascata', fenômeno comum hodiernamente e que tantos problemas traz para os trabalhadores.

Todavia, somente em 25 de fevereiro de 1967, com o Decreto-Lei $\mathrm{n}^{\circ}$ 200/67 (BRASIL, 1967), surgiu no direito brasileiro a primeira referência legal dispondo de forma direta e explícita sobre a permissão da terceirização. O seu conteúdo diz respeito às contrataçóes de serviços feitas por toda a Administração Pública Federal. O seu escopo, de acordo com o que dispóe o Capítulo III, art. $10, \$ 7$ ó a "descentralização do serviço público"s.

5 "Art. 10. A execução das atividades da Administração Federal deverá ser amplamente descentralizada. [...] $\S 7^{\circ}$ Para melhor desincumbir-se das tarefas de planejamento, coordenação, supervisão e controle e com o objetivo de impedir o crescimento desmesurado da máquina administrativa, a Administração procurará desobrigar-se da realização material de tarefas executivas, recorrendo, sempre que possível, à execução indireta, mediante contrato, desde que exista, na área, iniciativa privada suficientemente desenvolvida e capacitada a desempenhar os encargos de execução" (BRASIL, 1967). 
A audiência pública do TST sobre terceirização como espaço social de luta político-cognitiva | Attila Magno e Silva Barbosa e Rodrigo Hinz da Silva

Em 3 de janeiro de 1974, com a sanção da Lei nº.019/74, a chamada "Lei do Trabalho Temporário", apareceu no direito brasileiro o segundo instrumento legal tratando diretamente da terceirização. Essa lei permite que empresas contratem empresa especializada em fornecimento de mão de obra temporária em situaçóes justificadas, como substituição de empregados regulares devido ao afastamento por motivo de férias, licença-maternidade ou outro tipo de ocorrência e necessidade de aumento de produção ou de serviços em períodos excepcionais (BRASIL, 1964). O período de contratação é de três meses, prorrogável por mais três meses, caso comprovada sua necessidade mediante autorização do Ministério do Trabalho e do Emprego.

Em 1986, conforme apontam Biavaschi e Droppa (2011), adveio o entendimento jurisprudencial consolidado nos tribunais trabalhistas que gerou o Enunciado 6256 do TST, que dispunha: "[...] salvo os casos de trabalho temporário e de serviço de vigilância, previstos nas Leis no 6.019, de 03.01.1974, e 7.102, de 20.06.1983, é ilegal a contratação de trabalhadores por empresa interposta, formando-se o vínculo empregatício diretamente com o tomador dos serviços". O enunciado conferia mesmo tratamento para o fornecimento de mão de obra e para a terceirização, caracterizando assim como ilícitas as formas não reconhecidas em lei. Em 1993, o TST editou a Súmula 331, em substituiçấo ao enunciado 256 , a fim de corrigir essa confusão (BRASIL, 2000). Conforme destacam Biavaschi e Droppa (2011, p. 126):

Foi no vácuo da lei que o TST normatizou sobre essa forma de contratar; inicialmente, coibindo-a (Enunciado 256); mais tarde, legitimando-a em relação às atividades não essenciais ao empreendimento econômico, definindo como subsidiária a responsabilidade da tomadora (Súmula 331); em 2000, estendendo essa responsabilidade aos Entes Públicos que contratam terceiras.

A possibilidade de terceirizar funçóes cada vez mais próximas da atividade-fim das empresas possui um elemento estimulador: a dificuldade de se definir juridicamente o que pode ser enquadrado como atividade-fim e atividade-meio (náo essenciais) de um empreendimento econômico.

6 Os enunciados ou súmulas são o registro reiterado de interpretação pacifica ou majoritária adotada po um tribunal ante um tema especifico a partir do julgamento de casos análogos. Possuem dupla finalidade: publicizar a jurisprudência e promover a uniformidade das decisões nas diversas instâncias jurisdicionais. 
De acordo com Camino (2004), atividade-meio corresponde aos serviços de apoio e acessórios, mesmo que permanentes e necessários à atividade da empresa. Assim, depreende-se a possibilidade de sistematizaçáo de que os serviços não eventuais de uma empresa, aqueles que são considerados permanentes e necessários, constituem um gênero que abarca tanto as espécies de serviços essenciais ligados à atividade-fim empresarial como os serviços de apoio ligados a atividades-meio. Em oposição a esse gênero, há aquele que abarca os serviços eventuais ligados às necessidades circunstanciais, emergenciais, e prestados de modo pontual.

Vilhena (2001) considera que a classificação das atividades de uma empresa em atividade-fim e atividade-meio corresponde a uma questão de fato, na qual, se deve avaliar a estrutura organizacional de cada empresa. Nessa linha, deve-se considerar a autonomia com a qual os serviços terceirizados devem ser organizados, isto é, se tais serviços podem ou não ser destacados da atividade-fim e se não interferem de modo direto no processo de produção da empresa tomadora do serviço.

As empresas aproveitam-se dos pontos de inconsistência da Súmula 331 para estender o uso da terceirização. Até porque, como esclarece o ex-ministro do TST, Vantuil Abdala, um dos idealizadores da Súmula: "O enunciado apenas fornece uma orientação sobre a matéria e essa é a única sinalização que a sociedade possui no que concerne à terceirização" (ABDALA, 2004).

A jurisprudência do TST reconhece a possibilidade de terceirização nas funções que não se confundem com a atividade principal da empresa. Todavia, em outros tópicos considera a contratação de trabalhadores por empresa interposta como ilegal (exceto no trabalho temporário). Em casos assim, fica caracterizada a existência de vínculo empregatício com o tomador de serviços, impedida a formação de vínculo com órgãos da administração pública e impóe-se ao tomador de serviços a responsabilidade subsidiária por débitos trabalhistas.

A Súmula 331, diante da orientação do Enunciado 256, que considerava ilícita a terceirização, ampliou as possibilidades do seu uso ao limitá-la à atividade-meio da empresa e, consequentemente, acabou legalizando a intermediação de mão de obra (BRASIL, 2000). A esse respeito, o jurista Maior (2009, p. 160) alega que, a definição jurídica de terceirizaçáo nela contida "afastou-se da própria realidade produtiva". 
A audiência pública do TST sobre terceirização como espaço social de luta político-cognitiva | Attila Magno e Silva Barbosa e Rodrigo Hinz da Silva

A terceirização trata-se, como visto, de técnica administrativa, para possibilitar a especialização dos serviços empresariais. No entanto, o Enunciado 331, do TST, não vincula a legalidade da terceirização a qualquer especialização. Isto tem permitido, concretamente, que empresas de mera prestação de serviços sejam constituídas; empresas estas sem qualquer finalidade empresarial específica e, pior, sem idoneidade econômica. (MAIOR, 2009, p. 160).

Em uma postura extremamente crítica e combativa a tal permissividade, o referido jurista argumenta que o padrão jurídico criado

[...] desvinculou-se da função histórica do direito do trabalho, que é o da proteção do trabalhador. A perspectiva do Enunciado foi apenas a do empreendimento empresarial. Isto permitiu que a terceirização, que em tese se apresentava como método de eficiência da produção, passasse a ser utilizada como técnica de precarização das condições de trabalho. (MAIOR, 2009, p. 161).

Por sua vez, Silva (2011) e Martins Filho (2012) defendem que o uso da terceirização não deve ser limitado apenas à atividade-meio; afinal, bastaria para caracterizar sua licitude que não se apresentasse como mera estratégia para fraudar direitos trabalhistas. Esses autores alegam que o critério da atividade-fim e atividade-meio contido na Súmula 331 limita o poder decisório do administrador, concorrendo para o cerceamento do princípio da livre iniciativa consagrado no art. 170 da Constituição Federal (BRASIL, 1988) ${ }^{7}$.

A dificuldade em definir juridicamente o que seja atividade-fim e atividade-meio decorre da dinâmica das mudanças técnico-organizacionais processadas no atual estágio de acumulação capitalista. Isso porque, do ponto de vista empresarial, a fronteira entre as duas é bastante tênue, sendo essencialmente entendida como concernente à esfera de decisão do administrador e não da Justiça do Trabalho. Aqui, a estratégia empresarial de focalização é traduzida em termos jurídicos pela definição do critério da especialização de serviços como critério de licitude da terceirização.

As batalhas judiciais travadas nos tribunais trabalhistas brasileiros têm recrudescido com a ausência de um marco regulatório sobre a terceirização. Essa situação não apenas fomenta a luta político-cognitiva sobre os seus usos no âmbito da Justiça do Trabalho, mas, sobretudo, no âmbito da própria

7 Segundo o art. 170 da Constituição Federal: "A ordem econômica, fundada na valorização do trabalho humano e na livre iniciativa, tem por fim assegurar a todos existência digna, conforme os ditames da justiça social, observados os seguintes principios [...]" (BRASIL, 1988). 
sociedade. $\mathrm{O}$ momento de indefinição cria brechas legais que possibilitam às empresas reduzirem as funçóes ligadas à atividade-fim e, consequentemente, estenderem o uso da terceirização.

Percebe-se isso quando consideramos a classificação jurídica que distingue os tipos de terceirização de acordo com o tempo de duração da prestação de serviços: terceirização com duração determinada, caso do trabalho temporário, e terceirização com duração indeterminada. Juridicamente, entende-se que o trabalho temporário diferencia-se das outras formas de terceirização pela existência de subordinação jurídica direta e pessoalidade em relação à empresa tomadora de serviços e pela possibilidade de atuação do trabalhador temporário na atividade-fim ou na atividade-meio.

Excetuando o caso do trabalho temporário - para o qual o art. 11 da lei 6.019/74 expressamente dispóe que o "assalariado" será colocado à disposição da empresa tomadora (BRASIL, 1964) -, no mais, a jurisprudência no item III da Súmula 331 fixa a licitude da terceirização com base nos critérios da ausência de subordinação e de pessoalidade entre o trabalhador terceirizado e a tomadora de serviços (BRASIL, 2000). Do ponto de vista jurídico, disposiçôes como esta conferem licitude à terceirização, sendo a terceirização lícita designada "de prestação de serviços" e a ilícita como "locação de mão de obra".

Do ponto de vista empresarial, as filigranas jurídicas são o que menos importa, o mais relevante é a existência de um mínimo de respaldo legal que possibilite uma margem de manobra para a desoneraçáo de encargos trabalhistas ligados à contratação direta. A descaracterização jurídica da situação de "locação de mão de obra" em favor da situação "de prestação de serviços" produz "válvulas de escape" legais para o avanço do uso da terceirização.

Delgado (2002) admite ser a terceirização uma prática inerente ao mundo do trabalho contemporâneo; porém, adverte que ela não deve tornar-se referência para criação de outras formas de contrato precário. Defende que é necessário adaptar as suas ocorrências aos princípios provenientes do direito do trabalho e do direito constitucional. Para tal, propóe um "controle civilizatório da terceirizaçáo", que consistiria no estabelecimento de limites e de perspectivas de ingerência democrática sobre o seu uso com base nos princípios individuais do direito do trabalho ${ }^{8}$.

8 Esclareça-se, princípio da proteção do trabalhador, princípio da irrenunciabilidade de direitos, princípio da continuidade da relação de emprego e princípio da primazia da realidade. 
Delgado (2003) também ressalta que essa estratégia jurídica de controle ou de limites civilizatórios pode ocorrer com a consideração dos seguintes pontos: garantia de isonomia de remuneração entre os trabalhadores terceirizados e os trabalhadores diretos da empresa tomadora de serviços; responsabilidade do tomador de serviços pelos valores trabalhistas oriundos da terceirização e; fixação de vínculo sindical entre os trabalhadores terceirizados e o sindicato da categoria dos trabalhadores diretos da empresa tomadora de serviços.

Carelli (2007), em uma linha de entendimento próxima a essa, entende que, na prática empresarial brasileira, a terceirização já se confundiu com intermediação de mão de obra, assumindo uma dimensão maior do que a capacidade do Estado de proibi-la ou limitá-la como forma de organização empresarial. Para ele, a solução para os problemas gerados pelo uso da terceirização passa por uma posição proativa da legislação no sentido de proibir ou inibir a precarizaçáo de direitos que ela pode produzir. A luta deve ser no sentido de humanização da terceirização. Para tal, o autor propóe três dispositivos básicos: a responsabilidade solidária da tomadora de mão de obra pelas obrigaçóes trabalhistas referentes aos trabalhadores das terceirizadas ou subcontratadas; a isonomia de direitos e benefícios dos trabalhadores da empresa principal e daqueles das empresas subcontratadas, caso sejam superiores; e a possibilidade de sindicalizaçáo pelo sindicato da categoria dos trabalhadores da empresa principal (CARELLI, 2007, p. 66).

\section{Apontamentos metodológicos}

Antes de analisarmos a audiência pública do TST sobre terceirizaçáo, entendemos por bem realizar alguns apontamentos metodológicos sobre a pesquisa que deu origem a este artigo. Conforme será observado na seçáo seguinte, a referida audiência contou com a presença de 51 oradores selecionados por Edital de Convocação, mais quatro oradores que fizeram a abertura do evento (BRASIL, 2011a, 2011b), estes últimos, especificamente e na seguinte ordem: $\left.1^{\circ}\right)$ o Ministro-Presidente do TST (2011-2013); $\left.2^{\circ}\right)$ o Procurador-Geral do Trabalho; $3^{\circ}$ ) o Presidente do Conselho Federal da OAB (2010-2013); 4º) uma representante da Advocacia Geral da União. A audiência foi dividida em nove blocos temáticos: Abertura; Terceirização Geral; Marco Regulatório da Terceirização; Setor Bancário e Financeiro; Telecomunicações; Indústria; Serviços; Setor Elétrico; Tecnologia da Informação. A despeito de termos analisado todas as apresentaçóes, a nossa ênfase recaiu sobre os 24 oradores que compuseram os três primeiros blocos. Tal escolha foi feita por entendermos que as colocaçóes e os argumentos apresentados nesses blocos, de um 
modo geral, abarcam pontos de vista específicos apresentados pelos oradores dos blocos temáticos de cada ramo de atividade econômica. Vejamos a disposição dos oradores e de suas atividades:

Quadro I - Oradores da audiência pública do TST sobre terceirização

\begin{tabular}{|c|c|c|}
\hline Bloco & Nome & Atividade \\
\hline \multirow{18}{*}{$\begin{array}{l}\text { Terceirização } \\
\text { em } \\
\text { geral }\end{array}$} & José Pastore & $\begin{array}{c}\text { Sociólogo, Professor aposentado da Faculdade de } \\
\text { Economia e Administração da USP. }\end{array}$ \\
\hline & Ricardo Antunes & $\begin{array}{c}\text { Sociólogo, Professor Titular de Sociologia no Instituto de } \\
\text { Filosofia e Ciências Humanas da UNICAMP. }\end{array}$ \\
\hline & Gesner Oliveira & $\begin{array}{l}\text { Economista, Professor da FGV-SP, Representante do } \\
\text { Instituto ABRADEE da Energia. }\end{array}$ \\
\hline & Anselmo Luís dos Santos & $\begin{array}{l}\text { Economista, Diretor-Adjunto do Centro de Estudos } \\
\text { Sindicais e de Economia do Trabalho da UNICAMP. }\end{array}$ \\
\hline & Lívio Giosa & $\begin{array}{l}\text { Administrador de Empresas, Presidente do Centro } \\
\text { Nacional de Modernização Empresarial. }\end{array}$ \\
\hline & Clemente Ganz Lúcio & Sociólogo, Diretor técnico do DIEESE. \\
\hline & Márcio Milan & Representante da Confederação Nacional do Comércio. \\
\hline & $\begin{array}{l}\text { Maria da Graça Druck de } \\
\text { Faria } \\
\end{array}$ & $\begin{array}{c}\text { Professora do Departamento de Sociologia da FFCH da } \\
\text { UFBA, pesquisadora do CRH/UFBA. }\end{array}$ \\
\hline & Márcio Túlio Viana & $\begin{array}{c}\text { Desembargador aposentado do TRT } 3^{\text {a }} \text { Região, Professor } \\
\text { de Direito do Trabalho da UFMG e da PUC-MG. }\end{array}$ \\
\hline & Nelson Mannrich & $\begin{array}{l}\text { Professor titular de Direito do Trabalho da Faculdade de } \\
\text { Direito da USP. } \\
\end{array}$ \\
\hline & Rosângela Silva Rassy & $\begin{array}{c}\begin{array}{c}\text { Presidente do Sindicato Nacional dos Auditores-Fiscais } \\
\text { do Trabalho - SINAIT - }(2010-2011) .\end{array} \\
\end{array}$ \\
\hline & Adauto Duarte & $\begin{array}{l}\text { Diretor sindical da Federação das Indústrias do Estado de } \\
\text { São Paulo (FIESP). } \\
\end{array}$ \\
\hline & $\begin{array}{c}\text { Artur Henrique da Silva } \\
\text { Santos } \\
\end{array}$ & $\begin{array}{c}\text { Sociólogo, Presidente da Central Única dos } \\
\text { Trabalhadores (CUT). }\end{array}$ \\
\hline & Adriano Dutra da Silveira & Advogado, Consultor de empresas. \\
\hline & Sebastião Vieira Caixeta & $\begin{array}{l}\text { Presidente da Associação Nacional dos Procuradores do } \\
\text { Trabalho. } \\
\end{array}$ \\
\hline & Sônia Bridi & $\begin{array}{l}\text { Jornalista, Representante da Associação Brasileira das } \\
\text { Relações Empresa-Cliente. }\end{array}$ \\
\hline & Renato Henry Sant’anna & $\begin{array}{c}\text { Juiz do Trabalho da } 15^{\text {a }} \text { Região, Presidente da } \\
\text { ANAMATRA. }\end{array}$ \\
\hline & Márcio Pochmann & $\begin{array}{l}\text { Economista, Professor da UNICAMP, Presidente do } \\
\text { Instituto de Pesquisa Econômica Aplicada (IPEA). }\end{array}$ \\
\hline \multirow{2}{*}{\begin{tabular}{|l} 
Marco \\
regulatório \\
da \\
terceirização \\
\end{tabular}} & Sandro Mabel & $\begin{array}{c}\text { Deputado Federal PR-GO, Presidente do Conselho de } \\
\text { Administração do Grupo Mabel. }\end{array}$ \\
\hline & $\begin{array}{l}\text { Vicente Paulo da Silva } \\
\text { (Vicentinho) }\end{array}$ & $\begin{array}{c}\text { Deputado Federal PT-SP, Ex-Presidente da Central Única } \\
\text { dos Trabalhadores. }\end{array}$ \\
\hline
\end{tabular}

Fonte: Elaborada pelos autores. 
A audiência pública do TST sobre terceirização como espaço social de luta político-cognitiva | Attila Magno e Silva Barbosa e Rodrigo Hinz da Silva

Aqui, gostaríamos de esclarecer que optamos pela identificação dos oradores e de suas atividades, pois ainda que seus posicionamentos correspondam a pontos de vista particulares, estes não deixam de ser representativos de determinados posicionamentos que se fazem presentes na sociedade como um todo. Não por acaso, a escolha dos oradores pela Presidência do TST, segundo o despacho convocatório, levou em consideração a "[...] experiência e reconhecida autoridade em matéria de terceirização, objetivando esclarecer questôes fáticas, técnicas [...], cientificas, econômicas e sociais relativas ao fenômeno". Isto é, os oradores foram escolhidos devido ao destaque e à elevada influência que possuem enquanto agentes sociais nas suas respectivas áreas (jurídica, econômica, política, acadêmica etc.) de atuação, o que, mais precisamente, em termos sociológicos, corresponde aos seus capitais simbólicos acumulados.

A audiência pública foi televisionada ao vivo pelo canal "TV Justiça" e pelo site do TST na internet'. O percurso metodológico trilhado iniciou-se com o acompanhamento das apresentaçôes pelo menos duas vezes cada uma delas. Feito isso, fizemos as transcriçôes das apresentações correspondentes aos blocos de abertura, da terceirização em geral e do marco regulatório da terceirização. Essa estratégia nos permitiu a construçáo de um corpus textual a partir do qual identificamos alguns padrôes nos pronunciamentos dos oradores frente à terceirização.

Deste modo, o passo seguinte foi no sentido de compreender a audiência pública como um espaço social de luta político-cognitiva pela definição legítima do real. Isto é, das implicaçóes técnicas, jurídicas, sociais e econômicas dos usos da terceirizaçáo. E aqui, gostaríamos de ressaltar que se fez necessário de nossa parte um exercício contínuo de "vigilância epistemológica" (BOURDIEU; CHAMBOREDON; PASSERON, 2000), visto que tivemos que nos manter atentos frente à necessidade de policiarmos nosso próprio ponto de vista sobre o tema a fim de garantir ao máximo a confiabilidade dos dados obtidos e a adequação das categorias de entendimento por nós formuladas.

Todavia, tal vigilância não significou que tenhamos tido a pretensão de captar a integralidade da realidade social com a intenção de objetivá-la. O que procuramos fazer foi tão somente seguir as pistas metodológicas deixadas

9 VerTVTST, 20lla, 20llb, 20llc, 20lld, 20lle, 20l If. 
por Bourdieu (2011, p. 694), quando de suas críticas, ao que ele chamava de "sonho positivista de uma perfeita inocência epistemológica". E, por conseguinte, afirmava ser necessário "[...] se esforçar para conhecer e dominar o mais completamente possível seus atos, inevitáveis, de construção e os efeitos que eles produzem também inevitavelmente" (BOURDIEU, 2011, p. 694-695). Ou seja, o sociólogo, ao construir os modelos explicativos dos fenômenos sociais, pode acabar transmutando a compreensão racional desses fenômenos, ou mesmo de modo indireto, transformando empiricamente certas estruturas sociais, devido ao alcance de sua pesquisa. A esse respeito, Bourdieu (2011, p. 713) afirmava que:

O sociólogo não pode ignorar que é próprio de seu ponto de vista ser um ponto de vista sobre um ponto de vista. Ele não pode re-produzir o ponto de vista de seu objeto, e constituí-lo como tal, re-situando-o no espaço social, senão a partir deste ponto de vista muito singular (e, num sentido, muito privilegiado) onde deve se colocar para estar pronto a assumir (em pensamento) todos os pontos de vista possíveis. E é somente à medida que ele é capaz de se objetivar a si mesmo que pode, ficando no lugar que the é inexoravelmente destinado no mundo social, transportar-se em pensamento ao lugar onde se encontra seu objeto (que é também, ao mesmo em uma certa medida, um alter ego) e tomar assim seu ponto de vista, isso é, compreender que se estivesse, como se diz, no seu lugar, ele seria e pensaria, sem dúvida, como ele.

Assim, durante a análise dos diferentes pontos de vista sobre a terceirização, buscamos, nấo sem dificuldade, empreender a tarefa de colocarmo-nos, em pensamento, no lugar dos agentes sociais que estiveram presentes na audiência pública, procurando, assim, identificar os sentidos que cada orador confere ao fenômeno da terceirização.

A análise dos pronunciamentos nos permitiu a construção de categorias analíticas para a sistematizaçáo de grupos específicos de agentes, unidos pelo conjunto de suas ideias sobre o tema, o que possibilitou identificar as singularidades de cada uma das argumentaçóes e os elementos que constituem semelhanças, diferenças, complementaridades e antagonismos dos posicionamentos entre si. Esse procedimento nos permitiu construir quatro grupos de posicionamentos frente à terceirização, elaborados a partir dos principais pontos de argumentaçáo dos oradores. A partir disso, criamos um gradiente com os posicionamentos dos oradores, conforme se observará mais à frente no esquema ilustrativo do Quadro 2. 
A audiência pública do TST sobre terceirização como espaço social de luta político-cognitiva | Attila Magno e Silva Barbosa e Rodrigo Hinz da Silva

Gostaríamos de salientar que a tarefa que nos propusemos a realizar consistiu em identificar os "posicionamentos" dos agentes e não as "posiçôes sociais" por eles ocupadas, já que, a definição do espaço de suas posições sociais exigiria uma análise da relação destas com as "disposiçóes (ou os habitus) e as tomadas de posição, as "escolhas" que os agentes sociais fazem nos domínios mais diferentes da prática" (BOURDIEU, 2007b, p. 18). Em outras palavras, não fizemos uma análise relacional entre os habitus especificos, as posiçôes sociais e as tomadas de posição dos oradores enquanto agentes sociais; por conseguinte, não foi possível mapear as disposiçôes de cada um deles na extensão de toda a estrutura social. Esta tarefa não foi por nós empreendida, pois metodologicamente implicaria que tivéssemos realizado entrevistas em profundidade com todos os envolvidos, o que não foi viabilizado. Assim, tomamos como referente empírico apenas o espaço social da audiência pública.

A intenção de nossa construção tipológica foi mapear os pontos de vista apresentados na audiência pública, a fim de revelar como essa prática empresarial tem sido pensada nas suas implicaçóes jurídicas, sociais e econômicas. Para efeito de esclarecimento, nas palavras de Bourdieu (2007b, p. 21), tais disposiçôes correspondem:

\footnotetext{
Ao sistema de separações diferenciais, que definem as diferentes posições nos dois sistemas principais do espaço social [capital econômico e capital cultural], corresponde um sistema de separações diferenciais nas propriedades dos agentes (ou de classes construídas como agentes), isto é, em suas práticas e nos bens que possuem. A cada classe de posições corresponde uma classe de habitus (ou de gostos) produzidos pelos condicionamentos sociais associados à condição correspondente e, pela intermediação desses habitus e de suas capacidades geradoras, um conjunto sistemático de bens e de propriedades vinculadas entre si por uma afinidade de estilo.
}

Em termos analíticos, quando nos propusemos a analisar a audiência pública do TST sobre terceirização como um espaço social de lutas político-cognitivas, o que fizemos foi entendê-la como um espaço de forças opostas, o que implica afirmar que não se trata de inferir à qual posição assiste razão, mas sim que as posiçóes atuantes expressam "pontos de vista". Referimo-nos aqui, aos pontos nos quais os agentes se encontram e atuam na estrutura social, ao lugar do qual determinado entendimento sobre o mundo social tenta irradiar-se e impor-se como visão legítima sobre este. 


\section{Um espaço social de luta político-cognitiva}

Como dito na primeira seção, na ausência de um marco regulatório, a Súmula 331 (BRASIL, 2000) tem sido a principal referência jurídica sobre a terceirização para as decisões dos ministros do TST. Todavia, isto não implica considerar que não haja, no interior do referido tribunal, divergências de posicionamentos entre os ministros que o compõem. Podemos afirmar que, o principal ponto de discussão seja a insuficiência ou não do critério de atividade-fim e atividade-meio como definidor da licitude da terceirização. Outro ponto importante refere-se à necessidade de um marco regulatório.

Nesse sentido, o TST, diante da existência, em seu âmbito, de cerca de 5.000 recursos discutindo a licitude da terceirização, assim como de milhares de outros tramitando por toda a Justiça do Trabalho, em iniciativa inédita, convocou uma Audiência Pública com a finalidade de, nos termos do Edital de Convocação:

[...] ouvir o pronunciamento de pessoas com experiência e reconhecida autoridade em matéria de terceirização, objetivando esclarecer questões fáticas, técnicas (não jurídicas), científicas, econômicas e sociais relativas ao fenômeno da subcontratação de mão de obra [...] (BRASIL, 20IIC).

Realizada nos dias 4 e 5 de outubro de 2011, além dos quatro oradores do bloco de Abertura, foram selecionados 51 oradores de diversas correntes de opiniáo, entre juristas, economistas, sociólogos, sindicalistas, representantes patronais, parlamentares, administradores de empresa e outros para manifestarem-se em apresentaçóes de até 15 minutos, nas quais todos apresentaram informaçóes e defenderam seus argumentos e posicionamentos sobre o tema da terceirização. A disposição dos oradores se deu por blocos temáticos: terceirização em geral; marco regulatório da terceirização; setor bancário e setor financeiro; telecomunicaçóes; indústria; serviços; setor elétrico; e tecnologia da informação. Em seu discurso de abertura, o presidente do TST dispôs o seguinte:

A audiência pública emerge, pois, como um instrumento de maior legitimação das decisões do Tribunal. Denota uma postura de humildade da corte que se abre para o contato maduro e responsável com a sociedade [...]. Não obstante, ao definir a lista dos habilitados, buscamos contemplar todos os segmentos envolvidos, garantir a presença de especialistas e, em especial, assegurar a participação paritária do capital e do trabalho. [...] 0 objetivo 
A audiência pública do TST sobre terceirização como espaço social de luta político-cognitiva | Attila Magno e Silva Barbosa e Rodrigo Hinz da Silva

não é a coleta de opiniões jurídicas. Fosse tal o objetivo de certo que convocaríamos um seminário exclusivamente com juristas. Ademais, supõe-se que os ministros conhecem o direito [...]. Estamos convencidos que nesses dias de elevada especialização e acentuada globalização, a leitura dos fatos impõem-se multidisciplinar. Eis porque nesta audiência pública, convoca-se a sociedade civil para o auxilio no exercício da apreensão, seleção e compreensão dos fatos pelos magistrados [...]. De certa forma, na edificação da jurisprudência da corte será a superação da barreira do antigo brocado latino, segundo o qual o que não está nos autos não está no mundo. Em uma palavra, sobre terceirização, queremos trazer mais mundo para os autos.

As divergências e os antagonismos manifestados na audiência pública inserem-se em uma luta político-cognitiva mais abrangente, que versa sobre a flexibilização do direito do trabalho no Brasil. De toda forma, o objeto de disputas no caso da audiência pública foi a terceirizaçáo trabalhista, modalidade central da flexibilização das relaçôes de trabalho. Os argumentos apresentados pelos agentes sociais nortearam-se a partir de fatores como formação acadêmica, atuação profissional, engajamento político, participação em um campo específico de disputas (jurídico, econômico, político, sociológico, sindical etc.) e do capital simbólico adquirido nos respectivos campos de origem e das posiçốes nele ocupadas.

Além disso, esses agentes participaram da audiência na condição de representantes de um segmento da sociedade ${ }^{10}$. Em razão dessa relação dos agentes (de suas disposiçóes) com as posiçóes que ocupam na estrutura social, salvo importantes exceçôes, ao se considerar tanto o habitus (as regras específicas formadas a partir de sua autonomizaçáa) dos distintos campos, quanto dos agentes (a interiorização das disposições do campo), conseguimos identificar as motivaçóes de seus posicionamentos. É exatamente devido ao fato dos distintos campos possuírem regras específicas que surgem os antagonismos em relação a um mesmo objeto considerado.

A análise das apresentaçóes permitiu construir um gradiente de posicionamentos que considerou dois enquadramentos: $1^{\circ}$ ) o tipo de regulaçáo (se pública ou privada), visto que, entre os que defendem a primeira, temos dois grupos - os defensores de uma legislação fortemente restritiva e os defensores

10 Ainda que não seja possivel afirmar que representem totalmente os campos em que atuam (em decorrência das disputas existentes nos seus interiores), os agentes expressaram ideias e correntes existentes, representando segmentos desses campos e da própria sociedade. 
de uma legislação moderadamente restritiva -, já, entre os que alinham-se à segunda, também temos dois grupos - os defensores de uma legislação moderadamente permissiva e os defensores de uma legislação fortemente permissiva -, e nestes dois últimos, o entendimento comum é de que a negociação coletiva aparece como expressão normativa da autonomia privada coletiva das partes, o que significa que o negociado deve prevalecer sobre o legislado; $2^{\circ}$ ) os posicionamentos diante da flexibilização do direito do trabalho, abarcando quatro posicionamentos distintos: a) desconstrução legal do movimento flexibilizante; b) flexibilização de proteção, caracterizada pela imposição estatal de normas inderrogáveis pelas partes, favorecendo precipuamente o empregado; c) flexibilização de adaptação, correspondente ao ajuste das normas jurídicas às necessidades de produção ou aos momentos de crise econômica pela via da preponderância do negociado sobre o legislado; e d) flexibilização de desregulamentação, que consiste na minimização de direitos trabalhistas em favor da sobrevivência das empresas.

Quadro 2 - Gradiente representativo dos posicionamentos dos oradores na audiência pública

\begin{tabular}{|c|c|c|c|}
\hline \multicolumn{2}{|c|}{ Regulação Pública } & \multicolumn{2}{|c|}{ Regulação Privada } \\
\hline $\begin{array}{l}\text { Legislação fortemente } \\
\text { restritiva }\end{array}$ & $\begin{array}{c}\text { Legislação moderada- } \\
\text { mente restritiva }\end{array}$ & $\begin{array}{c}\text { Legislação moderada- } \\
\text { mente permissiva }\end{array}$ & $\begin{array}{c}\text { Legislação fortemente } \\
\text { permissiva }\end{array}$ \\
\hline 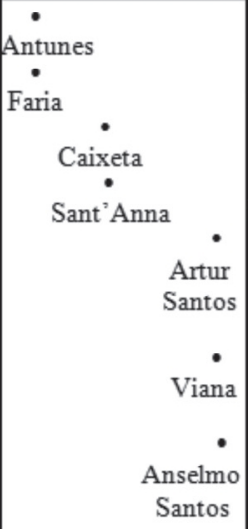 & $\begin{array}{l}\text { Vicentinho } \\
\text { Rúcio } \\
\text { Rassy } \\
\text { Pochmann }\end{array}$ & $\begin{array}{l}\text { Silveira } \\
\text { Milan } \\
\text { Mannrich } \\
\text { Pastore }\end{array}$ & $\begin{array}{l}\text { Oliveira } \\
\text { Duarte } \\
\text { Bridiosa } \\
\text { Mabel }\end{array}$ \\
\hline $\begin{array}{c}\text { Desconstrução } \\
\text { legal }\end{array}$ & $\begin{array}{c}\text { Flexibilizaccão de } \\
\text { proteção }\end{array}$ & $\begin{array}{l}\text { Flexibilização de } \\
\text { adaptação }\end{array}$ & $\begin{array}{l}\text { Flexibilização de } \\
\text { desregulamentação }\end{array}$ \\
\hline
\end{tabular}

Fonte: elaborado pelos autores 
A audiência pública do TST sobre terceirização como espaço social de luta político-cognitiva | Attila Magno e Silva Barbosa e Rodrigo Hinz da Silva

No primeiro grupo, situado na primeira coluna (à esquerda do gradiente), temos os agentes que possuem posicionamentos fortemente restritivos à terceirização. Tais agentes concordam ser necessário um marco regulatório para a terceirização a fim de impor limites rigorosos ao fenômeno, a ponto de, em um cenário ideal, defenderem que esse tipo de contrato de trabalho seja vedado pelo direito do trabalho brasileiro. Portanto, uma lei geral seria um primeiro passo no sentido da desconstrução jurídica da terceirização enquanto prática empresarial aceitável.

No segundo grupo (segunda coluna), temos os agentes que compóem os defensores de posicionamentos moderadamente restritivos. O seu foco principal é a abolição da terceirização que precariza direitos sociais, de maneira que não se observou a mesma ênfase em eliminar a figura da terceirização como um todo. O que se defende é que, se a terceirização impóe-se como uma prática inerente ao mundo empresarial atual, então, o que se deve fazer é regular essa forma de contratação visando a eliminar suas dimensóes precarizantes, procurando humanizá-la ou estabelecendo limites civilizatórios que oportunizem o acesso à proteção jurídica trabalhista.

O terceiro grupo é composto pelos agentes que integram a "Regulação Privada" (terceira coluna), e que defendem posicionamentos moderadamente permissivos. Os seus integrantes, a despeito de terem feito referência à questáo social, deram maior ênfase ao lado econômico da prática da terceirização, isto é, mesmo que tenham condenado a maneira como esta tem sido utilizada por algumas empresas no Brasil, náo a entendem como uma prática negativa pelo contrário, entendem-na como algo positivo -, pois atua como fator de competitividade das empresas e, por conseguinte, contribui diretamente para a criação de novas empresas e de novos postos de trabalho.

No quarto grupo, situado na coluna mais à direita do gradiente, temos os agentes que possuem posicionamentos fortemente permissivos à terceirização. O entendimento é o de que a terceirização deve ser liberada sem restrições. Os agentes nele inseridos defendem que a terceirização possibilita a realizaçáo de negócios que se tornariam inviáveis sem sua utilização. Mais do que contribuir para a competitividade empresarial, ela aparece aqui como uma estratégia empresarial que não apenas seria inerente ao atual estágio de desenvolvimento dos mercados globais, mas que fundamentalmente lhe permite as suas bases de reprodução. Para os integrantes deste grupo, a terceirização, se não chega a 
ser inevitável, ao menos é percebida como desejável para o fortalecimento da economia nacional. As suas ligaçôes e experiências com os setores empresariais são o fundamento cognitivo de pontos de vista que expressam uma naturalização da atual dinâmica econômica capitalista enquanto manifestação de uma ordem social legítima definitiva.

Em um posicionamento diametralmente antagônico ao dos integrantes do quarto grupo e de defesa incondicional da proteçáo de direitos sociais que são entendidos como conquistas históricas dos trabalhadores, o sociólogo Ricardo Antunes argumentou que a terceirização é a porta de entrada para a flexibilização, a precarização, e a informalidade. Ainda que reconheça que estas não sejam fenômenos idênticos, mas possuidoras de certas semelhanças, ele defende que "[...] a liberação ou a ampliação da terceirização vai ser um caminho mais seguro para o aumento da precarizaçâo estrutural do trabalho em escala global". E, ao se opor aos argumentos que versam sobre uma suposta "inevitabilidade" da terceirização como técnica empresarial em um contexto de economia globalizada, lembrou-nos de que a própria história já nos mostrou, algumas vezes, que não existe inevitabilidade histórica. O seu posicionamento, assim como o da também socióloga Maria da Graça Druck de Faria, é claramente contrário à terceirização. Como ambos entendem-na como negativa para os trabalhadores, é possível afirmarmos que, fundamentalmente, esses dois oradores posicionam-se em favor de uma legislaçáo fortemente restritiva que atue não apenas no sentido de promover a isonomia de direitos do trabalhador terceirizado mas também de desconstrução jurídica da terceirização; o que os coloca nas posiçóes mais à esquerda do gradiente.

O ponto de vista apresentado pelo também sociólogo Jose Pastore, orador localizado no terceiro grupo do gradiente, distingue-se claramente dos pontos de vista dos outros dois sociólogos acima citados. Isto porque, a despeito de reconhecer as dimensóes precarizantes que o uso da terceirização tem assumido no Brasil, ele a entende como um processo bastante complexo que corresponde a uma variedade muito grande de arranjos de trabalho. A esse respeito ele argumentou:

A terceirização não se refere a uma realidade, ela se refere a centenas e centenas de realidades diferentes. Sendo impossivel, portanto, administrar essas realidades diferentes com uma regra única, e muito menos como uma lei geral. Não há lei capaz de cobrir tamanha diversidade no campo da terceirização. 
A audiência pública do TST sobre terceirização como espaço social de luta político-cognitiva | Attila Magno e Silva Barbosa e Rodrigo Hinz da Silva

Em uma posição liberalizante, um pouco mais mitigada do que as dos oradores do quarto grupo, José Pastore defende que, se não fosse por meio do trabalho terceirizado, vários negócios seriam inviabilizados devido aos altos custos que estariam envolvidos no caráter descontínuo de determinadas atividades empresariais, por exemplo, o caso da construção civil. Deste modo, Pastore entende que a complexidade das relaçóes sociais não permite a adoção de uma mesma e única regra que abarque todas as situaçôes de terceirização, razão pela qual propóe regulamentar a terceirização em três níveis: "[...] lei, para proteçóes básicas; conselho (nacional), para proteçóes complementares, e acordos e convençôes para as proteçôes especificas por categoria". Em outras palavras, o que ele propóe é a combinação articulada em nível nacional de lei e negociação a fim de estabelecer proteçôes setoriais ou por ramos de atividade. Dessa forma, ainda que conceda ampla margem para uma regulação via negociação coletiva, a proposta de Pastore prevê disposições legais mínimas para tratar da terceirização.

Por meio de uma redefinição cognitiva do real, os agentes que se encontram nas duas colunas à direita do gradiente tentam disseminar as seguintes ideias sobre a terceirização: a) permite que a empresa seja organizada com base na focalização em sua atividade principal, deixando as atividades consideradas periféricas para terceiros; b) é uma técnica empresarial que contribui para a competitividade das empresas, pois desonera os custos com contratação direta e possibilita o aumento do investimento em novas tecnologias; c) o alargamento do seu uso permite a criação de "novos empregos".

Por outro lado, aqueles que se encontram inseridos nas duas colunas à esquerda do gradiente, defendem que tais argumentos, com frequência, desconsideram: a) que a criação de tais "empregos" não significa necessariamente trabalho protegido; b) que o estatuto jurídico dos terceirizados atua como fator de desmobilização da classe trabalhadora, pois lhes impóe o pertencimento a categorias distintas em um mesmo ambiente de trabalho; c) que a terceirização opera como estratégia de fragilização da capacidade de organização coletiva dos trabalhadores e de suas representaçóes sindicais.

Como em toda luta política, estamos lidando com situaçóes nas quais é necessário fazer escolhas e arcar com as consequências sociais, políticas e econômicas que delas decorrem. Do lado direito do gradiente, argumenta-se que o uso da terceirização não é uma mera técnica administrativa de 
redução de custos, mas, sobretudo, de focalização e aperfeiçoamento da expertise empresarial, o que possibilitaria o aumento da competitividade das empresas e a observação do princípio da livre iniciativa consagrado no art. 170 da Constituição Federal (BRASIL, 1988). Do lado esquerdo, argumenta-se que o direito do trabalho, enquanto direito social, deve promover o equilíbrio entre capital e trabalho, procurando limitar o poder econômico do primeiro e zelando pela efetividade do princípio da dignidade da pessoa humana nas relações de trabalho, como consta na Constituição Federal, art. 1, inciso III ${ }^{11}$; o que implica, se não forem decididas proibições expressas à terceirização, ao menos serão estipuladas medidas efetivas que combatam suas dimensóes precarizantes. Ademais, salientamos que há argumentos que tentam conciliar os dois polos, procurando encontrar um equilíbrio entre a necessidade de resguardar proteçōes trabalhistas aos trabalhadores terceirizados sem obstaculizar a livre iniciativa, isto é, a competitividade das empresas.

Analisando, por exemplo, os argumentos dos economistas Anselmo Santos e Márcio Pochmann no que diz respeito à questáo da competitividade espúria, nota-se que, apesar de ambos serem agentes do campo acadêmico que se encontram na mesma área de atuação, eles possuem posicionamentos distintos, mas não diríamos antagônicos. É o que se observa na afirmação de Pochmann, o qual comenta que, quando praticada de maneira correta, a terceirização leva ao crescimento econômico e que, por isso, apenas o que ele chama de "banda podre" precisa ser extirpado pela regulaçáa pública do trabalho. Por sua vez, Santos declara que inexiste uma relação efetiva entre terceirização e elevação dos níveis de competitividade empresarial e eficiência econômica, pois a terceirização seria, fundamentalmente, uma estratégia de redução de custos, constituindo-se, portanto, como uma forma de competitividade espúria que promove ganhos imediatos e não a melhoria das condiçóes que efetivamente propiciam o desenvolvimento econômico.

No entanto, o princípio de distinção que embasa as lutas simbólicas na estrutura social pode ser mais bem observado quando são contrapostos argumentos de agentes que defendem pontos de vista mais claramente antagônicos,

II "Art. $1^{\circ}$ A República Federativa do Brasil, formada pela união indissolúvel dos Estados e Municípios e do Distrito Federal, constitui-se em Estado Democrático de Direito e tem como fundamentos: [...] III - a dignidade da pessoa humana [...]". (BRASIL, 1988). 
A audiência pública do TST sobre terceirização como espaço social de luta político-cognitiva | Attila Magno e Silva Barbosa e Rodrigo Hinz da Silva

por exemplo, o caso dos economistas Anselmo Luís dos Santos e Gesner Oliveira. Este último, pertencente ao quarto grupo do gradiente, baseou sua argumentação no fato de que a terceirização seria um fator de competitividade que "[...] permite o fortalecimento da economia global, e consequentemente a geração de empregos", pois ela possibilita às empresas focalizarem em suas atividades centrais, isto é, "naquelas competências [...] que vão permitir melhores produtos e melhores serviços". Por sua vez, Santos, localizado no primeiro grupo do gradiente, apresentou argumentos fortemente contrários aos daqueles que defendem a terceirização como fator de competitividade:

O que nós vimos nos anos 1990 até 2002, com o avanço da flexibilização e da terceirização, não foi o aumento da competitividade da economia Brasileira, não foi o aumento da eficiência, não foi o aumento das empresas que inovam tecnologicamente. Nós vimos um processo imenso de redução de direitos expressos por uma ampliação descabida do assa lariamento sem carteira, mas também das cooperativas fraudulentas, da contratação de pessoas jurídicas ilegais. A terceirização, na grande maioria dos casos, não estou dizendo em todos eles, porque há casos de ganhos de eficiência econômica, o que são casos minoritários, é uma forma de competitividade espúria.

Os argumentos defendidos pelos oradores situados no quarto grupo do gradiente possuem uma forte complementaridade no que se refere à defesa da terceirização como fator de competitividade das empresas e de melhoria da qualidade dos produtos e dos serviços prestados ao consumidor. Lívio Giosa, por exemplo, defendeu o uso irrestrito da terceirização, propondo a abolição do critério da atividade-meio celebrado na Súmula 331 do TST (BRASIL, 2000). Afinal, conforme seu entendimento, a terceirização promove uma mudança técnico-organizacional de paradigma que possibilita a focalização das empresas "[...] no seu core business, na sua atividade principal. E, através disso, focando direto no seu tempo, na sua qualidade, sua dedicação, direcionamento de energias e visáo constante dos processos". Adauto Duarte, nessa mesma linha, defendeu que "[...] empresa se organiza em virtude do que ela é melhor [...]", e que "[...] limitar a terceirização incentiva a precarização, porque jogamos as pessoas na informalidade".

Os agentes que integram o quarto grupo quase não dão muita ênfase à precarização das relaçôes de trabalho e, quando dão, entendem-na como uma espécie distorção produzida pelo excesso de intervenção legislativa e judiciária. Tais posicionamentos, de clara inspiração neoliberal, evidenciam um 
alinhamento com o ideário hayekiano ${ }^{12}$ do mercado como ordem social. Nessa perspectiva, o papel que caberia ao Estado náo seria o de agente planejador central, mas tão somente o de promovedor dos enquadramentos jurídicos que possam vir a fortalecer a "ordem espontânea do mercado". Em outras palavras, cada caso de uso da terceirização deve ser analisado considerando as especificidades de cada ramo de atividade empresarial e não a partir de um pressuposto legislativo de proteção jurídica do trabalhador. Assim, a defesa é pela prevalência de modelos de "negociação direta entre capital e trabalho" como forma de regulação em detrimento de uma legislação trabalhista prévia. Em termos objetivos, a intenção é promover uma viragem ontológica (SAMPAIO, 2009) do Direito do Trabalho, pois a proteção do trabalho passa a ser entendida como uma proteçáo a quem o viabiliza, isto é, a empresa. Dito de outro modo, o que se deseja é que o Direito do Trabalho converta-se em uma espécie de Direito da Empresa e que a sua finalidade torne-se precipuamente a de uma pretensa regulação harmônica das relaçôes de trabalho, assegurando, portanto, as condiçôes de competitividade das empresas.

Considerando especificamente as apresentaçôes dos deputados federais Sandro Mabel e Vicente Paulo da Silva - o primeiro um representante legislativo que, segundo suas próprias palavras, tem "a honra de ser da turma empresarial' e o segundo é ex-presidente da maior central sindical brasileira, a CUT -, temos nelas um exemplo de uma disputa proveniente do campo político que evidencia, com mais clareza ainda, o princípio de distinção que embasa as lutas simbólicas na estrutura social.

O deputado Sandro Mabel, integrante do quarto grupo do gradiente, é o autor do Projeto de Lei no 4.330/2004 que objetiva regulamentar a terceirização e que tem como pontos centrais a definição da responsabilidade subsidiária da empresa contratante pelas obrigaçôes trabalhistas referentes ao período em que ocorrer a prestação de serviços, afastando a possibilidade da responsabilidade solidária e o reconhecimento de que a terceirizaçáo poderá incidir sobre a atividade econômica principal da empresa contratante. A esse respeito, ele defendeu que se possa "[...] terceirizar qualquer processo da empresa privada, pois hoje não é possivel distinguir atividade-meio de atividade-fim. Não existe mais isso de atividade-meio e atividade-fim". Além disso, Mabel se

12 Ver Ganem (20I2). 
A audiência pública do TST sobre terceirização como espaço social de luta político-cognitiva | Attila Magno e Silva Barbosa e Rodrigo Hinz da Silva

mostrou veementemente contrário ao reconhecimento legal do critério da responsabilidade solidária do tomador de serviços pelos débitos trabalhistas: "[...] nós temos que acabar com essa historia de superprodução a trabalhador terceirizado. Nós temos é que fazer com que a empresa que presta serviço terceirizado seja cobrada [...]"; e ele continua "[...] tomador de serviço não tem que ser solidário não, porque que ele tem que ser solidário? Quando uma empresa normal quebra, quem que é solidário? O governo paga, alguém paga? Não". É inegável o forte teor liberalizante do seu posicionamento.

Por sua vez, o deputado Vicente Paulo da Silva, integrante do segundo grupo do gradiente, iniciou sua fala dizendo: "[...] a minha reflexão é que, se nós pudéssemos não ter a terceirizaçâo, seria o ideal". Dito isto, ele defendeu um tipo de regulação pública que se inscreve nos limites fronteiriços entre uma legislação fortemente restritiva e uma legislação moderadamente permissiva, mas que, a despeito disso, converge para a defesa de uma flexibilização de proteção, o que evidencia uma postura de realismo político (realpolitik) de sua parte (WEBER, 1968). Ele também externou o seu temor em relação à possibilidade de aprovação na Câmara dos Deputados do projeto de autoria do deputado Sandro Mabel. No seu entendimento, a aprovação do Projeto de Lei $n^{\circ} 4.330 / 2004$ legalizaria a terceirização, possibilitando, também, a precarização dos direitos dos trabalhadores terceirizados.

De um modo geral, a despeito das divergências e dos antagonismos entre os pontos de vista apresentados pelos oradores, todos concordam que se faz necessário um marco regulatório sobre o tema, o cerne das divergências corresponde ao tipo de flexibilizaçáo que se considera admissível ou que se almeja. Contudo, além disso, é preciso discernir adequadamente os diversos posicionamentos a fim de classifica-los.

Deste modo, com base na análise das exposições, foi possível identificar quatro pontos fundamentais que nortearam a luta político-cognitiva sobre a terceirização na audiência pública: a) a definição do critério de licitude a ser adotado, se deve ser mantido ou suspenso o critério celebrado na Súmula 331 (BRASIL, 2000) ou se deve ser utilizado outro critério, por exemplo, o da especialização; b) a definição do tipo de responsabilidade do tomador de serviços, se solidária ou subsidiária pelas obrigaçóes trabalhistas; c) a questão da representação sindical, se deve ser ou náo a mesma para trabalhadores diretos e terceirizados que atuem no mesmo ramo de atividade; d) a discussão sobre a isonomia de direitos entre trabalhadores que exerçam a mesma função. 
Quanto mais à direita do gradiente, mais fortes ficam os seguintes entendimentos: a) que a decisão do que deve ser terceirizado fique a critério da avaliação das próprias empresas, observando, assim, o princípio da livre iniciativa, consagrado no art. 170 da Constituição Federal (BRASIL, 1988), pois não seria possível - na atual configuração da dinâmica empresarial - discernir com clareza o que seja atividade-fim de atividade-meio, devendo-se, se for o caso, optar pelo critério da especialização; b) que se defina legalmente a responsabilidade subsidiária tão somente quando a empresa tomadora de serviços fiscalizar o contrato; c) que as representações sindicais sejam distintas; d) que o trabalhador terceirizado tenha os mesmos direitos apenas no que se referir à sua presença física nas instalaçóes da tomadora de serviço, mas que, plano de saúde e outros benefícios incorporados ao salário sejam estritamente de responsabilidade da empresa prestadora de serviço, definidos em negociação coletiva.

Quanto mais próximo do centro do gradiente, mais fortes ficam os seguintes entendimentos: a) manutenção do critério de licitude e da definição da responsabilidade subsidiária como consta na Súmula 331(BRASIL, 2000); b) se mais à esquerda, defesa de uma mesma representação sindical; se mais à direita, defesa de representaçóes sindicais distintas; c) se mais à esquerda, isonomia salarial definida por lei; se mais à direita, a questão deve ser tratada em negociaçôes e acordos coletivos.

Quanto mais à esquerda do gradiente, mais fortes ficam os seguintes entendimentos: a) o recrudescimento do critério de licitude já celebrado pela Súmula 331 (BRASIL, 2000), procurando explicitar, o mais claramente possível, o que se entende por atividade-fim e atividade-meio; b) definição da responsabilidade solidária das empresas tomadoras de serviços como forma de obrigá-las a fiscalizar o contrato e, consequentemente, coibir a fraude aos direitos trabalhistas; c) mesma representação sindical para trabalhadores diretos e terceirizados visando ao fortalecimento desta; d) isonomia salarial entre trabalhadores diretos e terceirizados que exerçam mesmas funçôes de acordo com os parâmetros definidos por lei, por convençôes coletivas e acordos coletivos.

Fora dos limites da audiência pública, mas sobre ela lançando um olhar analítico, o ministro do TST Ives Gandra Martins Filho reconheceu os efeitos perversos que a terceirização, como forma de organização do trabalho, pode produzir: "[...] a) mera redução de custos; b) não integração do trabalhador 
A audiência pública do TST sobre terceirização como espaço social de luta político-cognitiva | Attila Magno e Silva Barbosa e Rodrigo Hinz da Silva

na empresa; c) descuido das normas de segurança e medicina do trabalho; d) precarização da relação de trabalho"; todavia, defende que "[...] não é possível nem conveniente tratar o fenômeno como nefasto em sua essência e esperar do TST a sua desconstrução, como pretendido por alguns dos participantes na referida audiência” (MARTINS FILHO, 20012, p. 12). Assim, ele entende que:

Com efeito, a competitividade empresarial própria da economia de mercado, somada ao desenvolvimento tecnológico, aponta para a especialização como caminho a ser trilhado para se chegar ao aumento da qualidade do bem ou serviço oferecido. Quanto mais especializado é um médico, advogado ou fornecedor, mais ele passa a ser procurado, por atender melhor à necessidade específica das pessoas (MARTINS FILHO, 2012, p. 13, grifos do autor).

Martins Filho (2012, p. 13) admite a flexibilização das leis trabalhistas como uma forma de enfrentar as crises econômicas e defende a autonomia do instrumento da negociação coletiva. Alega que a "terceirização não é um mal em si mesmo", mas sim um fenômeno econômico generalizado, porém, adverte que é preciso compreender melhor a sua essência para que seja possível corrigir suas distorçôes pela via da "[...] intervenção estatal no domínio econômico, naquilo que atenta contra os direitos humanos fundamentais, entre os quais o do trabalho".

Considerando que o espaço social da audiência pública configurou-se a partir da iniciativa de um dos órgãos do poder judiciário, faz-se necessário ter em vista, como indica Bourdieu (1998a), que o Estado é uma realidade ambígua que não se constitui como mero instrumento a serviço dos grupos dominantes, já que, apesar de não ser neutro, pode desenvolver certa autonomia e força a partir da condição de antiguidade enquanto lugar de incorporação e registro de conquistas sociais em suas estruturas. A persistência de um quadro de fragilização de direitos tende a naturalizar situaçóes que - longe de serem produtos de um regime econômico regido por leis inflexíveis que expressam uma espécie de "natureza" dos mercados capitalistas - são manifestações de um regime político instaurado náo apenas por meio da simples anuência dos poderes realmente políticos, mas, com a cumplicidade passiva ou ativa destes.

Podemos afirmar que a convocação da audiência pública constituiu-se em uma ação do TST no sentido de promover a ampliação do debate público sobre o tema, visto que não o circunscreveu aos limites do campo jurídico. 
O principal objetivo foi fazer emergir, se não uma visão definitiva no âmbito do TST, ao menos uma visão mais bem consubstanciada sobre as implicações técnicas, sociais e econômicas que o uso da terceirização produz e que a sua eventual extensão pode produzir.

Essa iniciativa não parece indicar, ao menos nesse episódio, uma disposição do TST em anuir ou atuar passiva ou ativamente como cúmplice do regime político que está "por trás" do regime econômico que tenta apresentar-se como racionalmente neutro, quando da defesa da flexibilização do direito do trabalho. O que se viu foi a constituição de um espaço social em que argumentos e posicionamentos dos mais diferentes matizes foram apresentados, alguns, inclusive, diametralmente antagônicos.

\section{Considerações finais}

É possível notar que, ao nomear relaçôes de trabalho que fragilizam os elementos constitutivos do contrato por tempo indeterminado de trabalho como novas formas de emprego, os discursos pró-flexibilização - e aqui estão incluídos os defensores da flexibilização de adaptação e da flexibilização de desregulamentação - tentam minar as resistências no campo jurídico e, gradativamente, imiscuir-se na socializaçáo das geraçôes futuras por meio de uma redefinição cognitiva do real.

$\mathrm{O}$ avanço desse movimento tende a criar um horizonte de valores não mais alicerçados no princípio da proteção do trabalhador que deu origem à CLT, mesmo que este jamais tenha se espraiado e efetivado plenamente no mercado de trabalho brasileiro. Todavia, mesmo que tal situação venha ganhando força nas últimas duas décadas, ela não deixa de criar tensões e resistências, visto que é uma construção social e não uma "ordem natural" das coisas, como vociferam os que tentam lhe dar suporte.

Não apenas a diversidade mas também os antagonismos dos pontos de vista manifestados pelos agentes sociais que se fizeram presentes na audiência pública do TST sobre terceirização evidenciam a dinâmica desta luta político-cognitiva que instaura movimentos pendulares de construção/desconstrução e naturalização/desnaturalização da realidade social concernente à terceirização.

A referida audiência pode ser considerada como um dos principais espaços sociais nos quais a luta político-cognitiva sobre a terceirizaçấo tem sido 
A audiência pública do TST sobre terceirização como espaço social de luta político-cognitiva | Attila Magno e Silva Barbosa e Rodrigo Hinz da Silva

travada no Brasil. Uma luta que, a despeito de parecer neste momento pender para uma maior flexibilização do direito do trabalho, ainda não tem definida qual tipo de flexibilização prevalecerá, se de proteção, adaptação ou desregulamentação.

Consideramos que o forte enraizamento da Justiça do Trabalho e da CLT na vida jurídica e social brasileira, instituídos precipuamente para equilibrar a relação entre capital e trabalho e com o intuito de amenizar e proteger a parte hipossuficiente, isto é, o trabalhador, apresentam-se como um obstáculo considerável ao último tipo de flexibilização. Nesse sentido, arriscamo-nos a afirmar que a tendência a ser seguida é a de criação de um marco regulatório que fique entre uma flexibilização de proteção e uma flexibilização de adaptação ou, até mesmo, a algum tipo de hibridização entre as duas.

\section{Referências}

ABDALA, Vantuil. País precisa regulamentar trabalho terceirizado, diz presidente do TST. Folha Online. 5 ago. 2004. Disponível em: <http://www2.uol.com.br/aprendiz/guiadeempregos/ primeiro/noticias/ge050804.htm\#1>. Acesso em: 16 set. 2011.

BIAVASCHI, Magda Barros; DROPPA, Alisson. A história da súmula 331 do Tribunal Superior do Trabalho: a alteração na forma de compreender a terceirização. Mediaçóes, Londrina, v. 16, n. 1, p. 124-141, jan./jun. 2011

BOURDIEU, Pierre. A miséria do mundo. Petrópolis: Vozes, 2011.

Coisas ditas. São Paulo: Brasiliense, 2004.

Contrafogos: táticas para enfrentar a invasão neoliberal. Rio de Janeiro: Jorge Zahar Editor, 1998 a.

Meditaçóes pascalianas. 2. ed. Rio de Janeiro: Bertrand Brasil, 2007a.

O poder simbólico. Rio de Janeiro: Bertrand Brasil, $1998 \mathrm{~b}$.

Razóes práticas. 8. ed. Campinas: Papirus, 2007b.

; CHAMBOREDON, Jean-Claude; PASSERON, Jean-Claude. A profissáo de sociólogo:

preliminares epistemológicos. Tradução de Guilherme João de Freitas Teixeira. 2. ed. Petrópolis: Vozes, 2000.

BRASIL. Constituição (1988). Constituição da República Federativa do Brasil de 1988. Disponível em: <http://www.planalto.gov.br/ccivil_03/constituicao/constituicao.htm>. Acesso em: 16 set. 2011. 
Decreto-Lei no 200, de 25 de fevereiro de 1967. Dispóe sôbre a organizaçáo da Administração Federal, estabelece diretrizes para a Reforma Administrativa e dá outras providências. Diário Oficial da Uniáo, Brasília, DF, 25 fev. 1967. Disponível em: <http://www.planalto.gov.br/ ccivil_03/decreto-lei/Del0200.htm>. Acesso em: 16 set. 2011.

Lei no 6.019, de 3 de janeiro de 1974. Dispóe sobre o Trabalho Temporário nas Empresas Urbanas, e dá outras Providências. Diário Oficial da Uniáo, Brasília, DF, 3 jan. 1974. Disponível em: <http://www.planalto.gov.br/CCIVIL_03/leis/L6019.htm>. Acesso em: 16 set. 2011.

Tribunal Superior do Trabalho. Despacho de habilitaçáo de participantes da audiência pública, em 5 de setembro de 2011. Diário Eletrônico da Justiça do Trabalho, Brasília, DF, n. 810, 8 set. 2011a. [Caderno do] Tribunal Superior do Trabalho, p. 2-4. <http://aplicacao.tst.jus.br/ dspace/handle/1939/16178>. Acesso em: 16 set. 2011.

Despacho [do Presidente do Tribunal Superior do Trabalho], de 27 de setembro de 2011: audiência pública sobre terceirização. Diário Eletrônico da Justiça do Trabalho, Brasília, DF, n. 826, 30 set. 2011b. [Caderno do] Tribunal Superior do Trabalho, p. 1-3. <http://aplicacao. tst.jus.br/dspace/handle/1939/16602>. Acesso em: 16 set. 2011.

Edital de Convocação de Audiência Pública, de 4 de agosto de 2011. Diário

Eletrônico da Justiça do Trabalho, Brasília, DF, n. 787, 5 ago. 2011. [Caderno do] Tribunal Superior do Trabalho, p. 6-7. Republicado no Diário Eletrônico da Justiça do Trabalho, Brasília, DF, n. 788, 8 ago. 2011. [Caderno do] Tribunal Superior do Trabalho, p. 5. Republicado no Diário Eletrônico da Justiça do Trabalho, Brasília, DF, n. 789, 9 ago. 2011c. [Caderno do] Tribunal Superior do Trabalho, p. 9. <http://aplicacao.tst.jus.br/dspace/handle/1939/14756>. Acesso em: 16 set. 2011.

TST Enunciado no 331 - Revisão da Súmula no 256. 2000. Disponível em: <http://www.dji.com.br/normas_inferiores/enunciado_tst/tst_0331a0360.htm>. Acesso em: 11 dez. 2010.

CAMINO, Carmen. Direito individual do trabalho. 4. ed. Porto Alegre: Síntese, 2004.

CARELLI, Rodrigo de Lacerda. Formas atípicas de trabalho. São Paulo: LTr, 2010.

Terceirização e direitos trabalhistas no Brasil. In: DRUCK, Graça; FRANCO, Tânia. A perda da razão social do trabalho. São Paulo: Boitempo, 2007. p. 59-68.

DELGADO, Gabriela Neves. Terceirização: paradoxo do direito do trabalho contemporâneo. São Paulo: LTr, 2003.

DELGADO, Maurício Godinho. Curso de direito do trabalho. São Paulo: LTr, 2002. 
A audiência pública do TST sobre terceirização como espaço social de luta político-cognitiva | Attila Magno e Silva Barbosa e Rodrigo Hinz da Silva

GANEM, Angela. Hayek: do mercado como ordem espontânea ao mercado como fim da história. Política \& Sociedade, v. 12, p. 93-117, 2012.

MAIOR, Jorge Luiz Souto. Trabalho descentralizado: a terceirizaçâo sobre uma perspectiva humanista. Revista Latinoamericana de Derecho Social, n. 9, p. 159-174, jul./dic. 2009.

MARTINS FILHO, Ives Gandra da Silva. O fenômeno da terceirização e suas implicações jurídicas. Direito Público, Porto Alegre, v. 8, n. 43, p. 9-27, jan./fev. 2012.

SAMPAIO, Murilo, Carvalho Oliveira. (Re)pensando o principio da proteçáo na contemporaneidade. São Paulo: LTr, 2009.

SILVA, Antônio Álvares da. Globalizaçáo, terceirização e a nova visão do tema pelo Supremo Tribunal Federal. São Paulo: LTr, 2011.

TV TST. Audiência Pública Terceirização - Terceirização em Geral - Parte 1. 2011a. 1 post (48 min 43 s). Postado em: 7 de out de 2011. Disponível em: <https://www.youtube.com/ watch?v=CCCmoCnzfQk>. Acesso em: 8 out. 2011.

. Audiência Pública Terceirização - Terceirização em Geral - Parte 2. 2011b. 1 post (59 min 6 s). Postado em: 10 out 2011. Disponível em: <https://www.youtube.com/watch?v=ldcpGs $1 \mathrm{kRmI}$. Acesso em: 11 out. 2011.

Audiência Pública Terceirização - Terceirização em Geral - Parte 3. 2011c. 1 post $(35$ min 18 s). Postado em: 10 out 2011. Disponível em: <https://www.youtube.com/ watch?v=MrTZtZgpl5k>. Acesso em: 11 out. 2011

Audiência Pública Terceirização - Terceirização em Geral - Parte 4. 2011d. 1 post (41 min 43 s). Postado em: 10 out 2011. Disponível em: <https://www.youtube.com/watch?v=_ IBVGDStCjQ>. Acesso em: 11 out. 2011.

Audiência Pública Terceirização - Terceirizaçáo em Geral - Parte 5. 2011e. 1 post (49 min 54 s). Postado em: 10 out 2011. Disponível em: <https://www.youtube.com/ watch?v=ZyqvyZGNmkI>. Acesso em: 11 out. 2011

Audiência Pública Terceirizaçáo - Terceirização em Geral - Parte 6. 2011f. 1 post $(54 \mathrm{~min} 7 \mathrm{~s})$. Postado em: 10 out 2011. Disponível em: <https://www.youtube.com/ watch?v=nTiNWDuDpwk>. Acesso em: 11 out. 2011.

VILHENA, Paulo Emílio Ribeiro de. Recursos trabalhistas e outros estudos de direito e processo do trabalho. Sấo Paulo: LTr, 2001.

WEBER, Max. Ciência e política: duas vocaçóes. Tradução de Leônidas Hegenberg; Octavio Silveira da Mota. São Paulo: Cultrix, 1968. 


\section{The Brazilian Superior Labour Court Hearing on outsourcing as a social space for political-cognitive struggle}

\section{Abstract}

The Brazilian Superior Labour Court, by considering the existence in its scope of about 5,000 resources discussing the legality of outsourcing, as well as thousands of other resources being processed throughout the Brazilian Labor Courts, on unprecedented initiative, convened on august 9th, 2011, a Public Hearing to discuss outsourcing. Occurred on October 4th and 5th, 2011 , fifty-one speakers from various lines of thought were selected among lawyers, economists, sociologists, trade unionists, employers'representatives, parliamentarians and business managers, to talk in 15 minutes presentations, in order to express their arguments, positions and information on the subject. Such an event aimed to help in providing, if not a definitive view, at least a better view on the social, economic and political implications that outsourcing and its possible extensions, may produce. Therefore, this article aims to examine such public audience as a socialcognitive space for political struggles over the definition of the real. Which means, in this case, to comprehend the searching from TST for a line of understanding on the topic of outsourcing, from information, arguments, and placements brought by various social agents that were present in the Public Hearing.

Keywords: Flexibilization of employment relations. Outsourcing. Political-cognitive struggle. 